\title{
A Remnant of a Gislenian Anthology
}

by

\author{
Leszek Wysocki and Richard Virr
}

This article discusses the indentification of the constituent parts of a manuscript volume held in the Department of Rare Books and Special Collections, McLennan Library. It has the shelf mark "de Ricci 118," and the only published reference to it is in Seymour de Ricci, Census of Medieval and Renaissance Manuscripts, II, 2214. The description there is sufficiently brief so as to be misleading when it is not erroneous.

This manuscript volume is a compilation of various hagiographical texts linked with the cult of the VIIth century Belgian saint, Gislenus, and a truncated text of Peter Riga's Aurora. In this article, the various Gislenian texts are identified and their history reconstructed. It is upon this basis that the fragments have been identified as the remnants of a codex, Cellensis MMMM, held originally in the library of the monastery of St. Gislenus, then transferred to Mons where finally the library was dispersed and this codex believed to be lost without trace.

Dans cet article, les auteurs parlent de l'indentification des parties constituantes d'un manuscrit que se trouve au Département des livres rares et des collections spéciales de la bibliothèque McLennan. Ce volume porte la cote "de Ricci 118" et la seule référence publiée qui existe à son sujet figure dans l'ouvrage de Seymour de Ricci, Census of Medieval and Renaissance Manuscripts, II, 2214. La description y est suffisamment brève pour être trompeuse, quand elle n'est pas erronnée.

Ce volume est une compilation de divers textes hagiographiques liés au culte d'un Saint belge du VII ${ }^{e}$ siècle, St-Gislenus, et d'un texte tronqué de l'Aurora de Peter Riga. Dans cet article, les divers textes de Gislenus sont identifiés et leur histoire est reconstituées. C'est gráce à cela que les fragments ont été identifiés comme les vestiges d'un manuscrit ancien, Cellensis MMMM, qui se trouvait à l'origine dans la bibliothèque du monastère de St-Gislenus avant d'être transféré à Mons dont la bibliothèque finit par être dispersée, ce qui laissa croire que ce manuscrit ancien avait été perdu sans laisser de trace.

In the mediaeval manuscript collection of the Department of Rare Books and Special Collections, McLennan Library, is a volume (MS 118) in a late nineteenth century binding containing material described as "Commemoratio $\mathrm{S}$. Gilenii," "Metrical abbrevation of the Bible in Latin" and "Vita S. Gilenii."1 This composite volume of items from the XIIIth and XIVth centuries would appear never to have been examined in any detail. The "metrical abbrevation of the Bible in Latin" is, in fact, a fragment of the third redaction of Peter Riga's famous poem Aurora. The two other items bound together with this truncated text are the subject of this paper.

The ten leaves of the "Commemoratio S. Gilenii" and the "Vita S. 
Gilenii" are all foliated in Roman numerals by the same hand. One leaf (lxxxxvi) precedes Riga's poem while the remaining nine leaves are bound at the end of the volume after the Aurora. These nine leaves are foliated clxxxxvii to ccv. Although the coincidence of decimal and unitary digits between the foliation signs of the first leaf and last nine is striking, the possibility that on the first folio a "c" preceded lxxxxvi as the foliation mark must be excluded absolutely. Therefore, it is clear that of the original codex, one hundred leaves are lost from between the two remaining fragments as well as 95 leaves from the beginning. We will return to this problem in the conclusion of our article.

We may assume fairly safely that these ten leaves, containing several texts primarily concerning St. Gislenus, belonged at some point to an anthology of literature dealing with this obscure VIIth century Belgian saint. $^{2}$ However, before we present any hypotheses concerning the history of the codex from which the leaves originally came, we should analyse briefly the texts contained in them, especially since these have never been adequately identified or described.

A. The first leaf (f. $1 /$ lxxxxvi) contains:

1. On the recto, "Prosa de sancto Gisleno." The title in red was probably added later since in the text the saint is referred to as Gillenus. The "prosa" has thirteen lines with musical notation.

Beg.: Exultemus in hac die, sonent dulces melodiae.

Ends: in eorum medio vivit et regnat.

2. On the verso, three hymns to the saint. The rubrics were probably written by a later hand, but a different one from that which added the title on the previous page. Musical notation is given only for the first strophe of each hymn since, unlike that in the "prosa," all strophes in each hymn have the same rhythm (Figure 15).

a. In festo sancti Gilleni hymnus ad vesperos.

Beg.: Nos afflictos aestu vel pluvia,

Ends: Cui laus sit, honor, imperium.

b. Ad (completorium?): this seems to be the only possible reading of the illegible rubric in our manuscript, although we could expect here as well a hymn "ad nonas" or "ad nocturum;" the latter rubric would accord best with the third line of the hymn, "sic instare nocturnis cantibus."

Beg.: Pulsis longe sompni vaporibus

Ends: Patri, Nato, Sancto spiritui.

c. Ad laudes. 


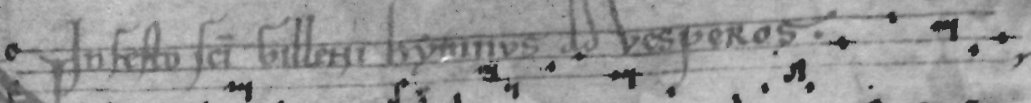

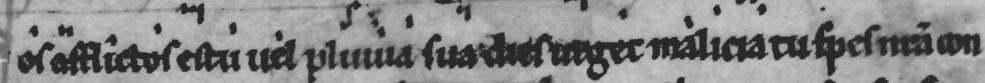

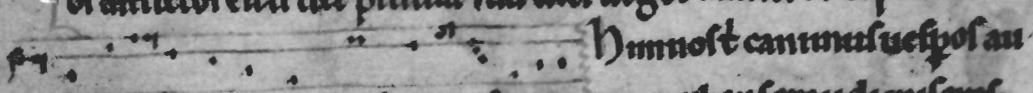

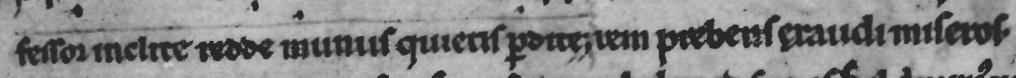

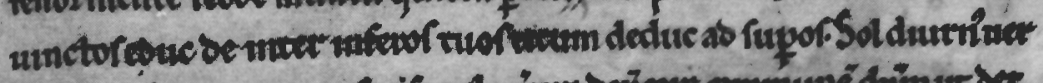

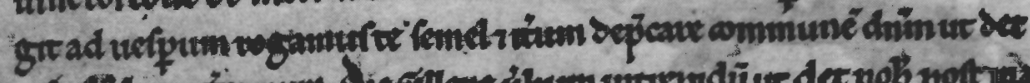

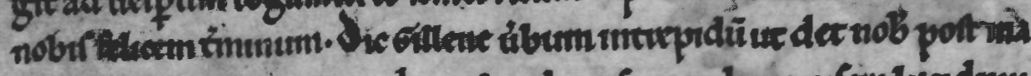

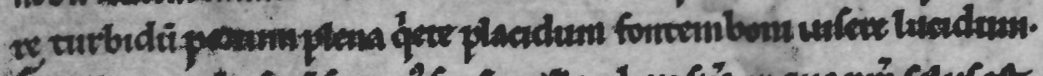

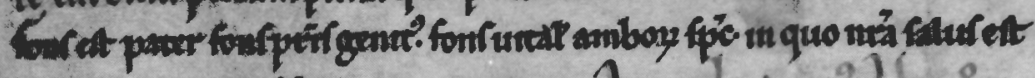

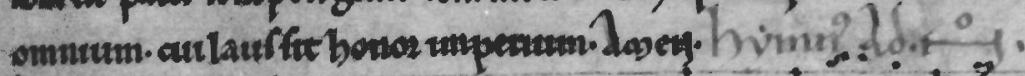

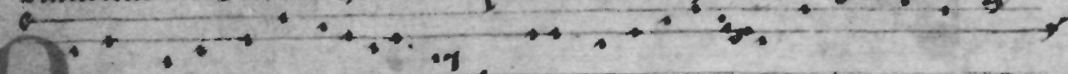

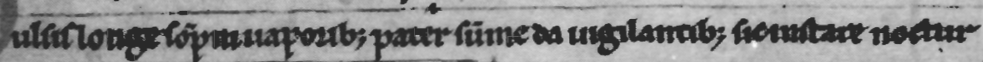

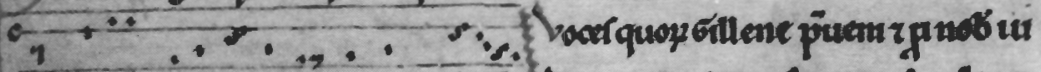

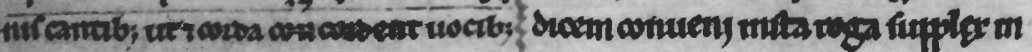

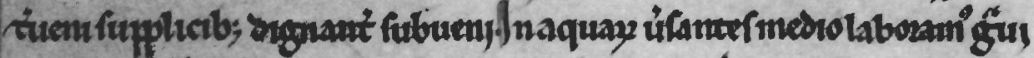

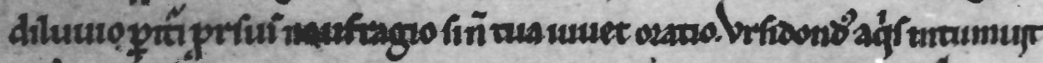

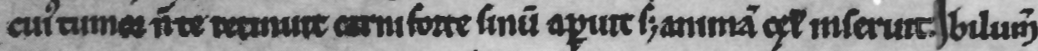

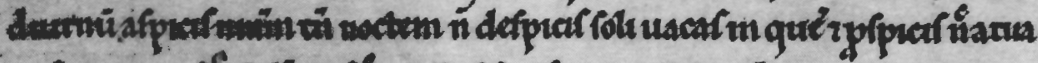

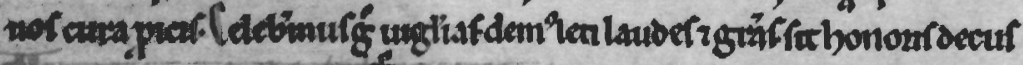

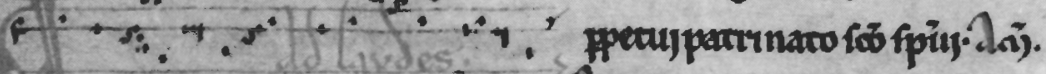

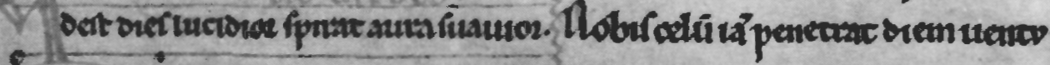

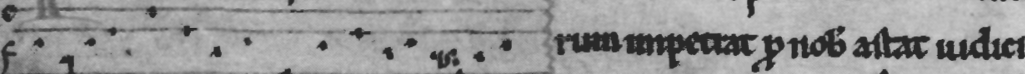

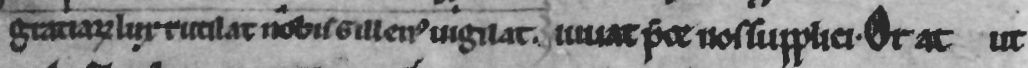

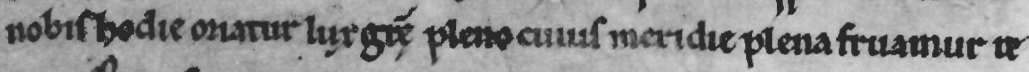

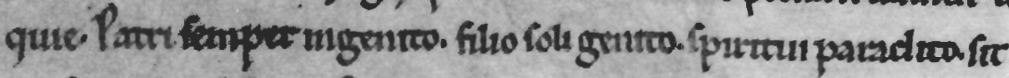
laul bonose debre. 2 a)

Fig. 15. Office hymns in honour of St. Gislenus (f. Iv). (Courtesy of Department of Rare Books and Special Collections) 
Beg.: Adest dies lucidior

Ends: Sit laus honore debito.

A few words should be said about these four texts. "Prosa" is a technical term for a religious lyric. Originally it referred to a prose hagiographical text, but in the XIIth century it came to indicate a poem with a responsion of polysyllabic strophes sung antiphonally on the melody of the Alleluia in the Gradual and of the "Ite missa est" at the end of the Mass. Some time later the "prosa" developed into a genre independent of the liturgy. Our "prosa" seems to represent the transitional form and can be dated to the late XIIth or early XIIIth century. Twelve polymorphic strophes can be recognized though the text is written continuously without the colometry. $^{3}$ The same applies to the three hymns which also have no colometry indicated in the manuscript. These three hymns to St. Gislenus are among the very few hymns in honour of this saint. There is a similar triad of hymns in the codex Cellensis KKKK, later known as Montensis 221 (alias 27 vel 8401), "Officium sancti Gisleni,"4 together with some other hymns, ${ }^{5}$ of which two, "ad magnificat" and "in 1 vesperis," are also recorded in the codex Coloniensis 28 (f. 202a) ${ }^{6}$

Our "prosa" and hymns were discovered and published by A. Poncelet as an appendix to his annotated Vilae sancti Gisleni published in $1887 .^{7}$ It would seem that our manuscript is the only surviving codex with these texts except for the one from which they were published by Poncelet. He describes this codex rather ambiguously, saying only that these texts were "in $4^{0}$ corio rubro exscripti." 8 About the dating of these hymns, he is equally imprecise, saying simply "antiquam aetatem redolere videntur." Palaeographical features of our manuscript would suggest that it should be dated at the beginning of the XIIIth century. Finally, we should note that Poncelet's manuscript has one corrupt reading in the penultimate line of the hymn "ad laudes" where "paracleto" appears, while our manuscript has the correct reading "paraclito." However, we should not consider this to be a clue for the relative dating of these two manuscripts, since this word is supposed to rhyme with three other words ending with "ito" and any scribe, even without a great command of Latin, would be able to spot an error here and correct it himself.

B. ff. 60-68 of the complete volume (clxxxxvii-ccv) contain four different texts that in the de Ricci description are treated as one, "Vita sancti Gilleni."

1. f. 60 (clxxxxvii) recto contains twenty lines of "subscriptiones" listing twenty-two names of bishops and archbishops who give their approval to a decree of Pope Stephen, with a marginal note indicating some "error in scriptione" that is unclear. On palaeographical grounds this leaf should be dated as being XIIIth century. The text is in black with the initial in red and the capital letters stroked in red except for line 17 mentioning Bishop Ainardus that was filled in later. In two other places it seems that names of bishops were added in blanks left by the scribe: $l .12$ Hi(1)duinus and $l .19$ - Richininus. In addition, the name of Agapitus was written originally without the ending which was added later together with his title, "episcopus." Since, at least on the 


\section{A Remnant of a Gislenian Anthology}

surface, there is no direct link between these "subscriptiones episcoporum" and the other material concerning St. Gislenus, we will postpone the discussion of this document to the end of our article (Figure 16).

2. f. 60 verso contains a brief sixteen line diet and other counter measures against the malady of St. Gislenus, "morbus beati Gilleni," which term most probably refers to epilepsy. ${ }^{9}$ This text is written by the same XIVth century hand as the texts on the following leaves.

Beg.: Haec sunt observanda singulis qui in morbo beati Gilleni incidunt.

Ends: Nihil horum absque thesaurarii licentia aut consilio relaxare.

This line has been crossed out by a later hand, perhaps the same one that made a marginal remark on the preceding page, and some illegible comment is added at the end of the text.

3. ff. 61-66 (clxxxxviii-cciii) contain a versified "Vita sancti Gisleni" and "De miranda re sancti." The text is written in an early XIVth century script with $27 / 28$ lines per page in a single column and every tenth line is marked in the margin by the sign " $T$," but by the middle of the poem this sign appears less regularly. The text is in the same hand as the recipe and has the superscription, probably by a different hand, "Famulus Jesu Christi nunciavit multa (illa?). The text of the vita proper begins (f. 61r):

Supplex oro veni me, Kyri sancte, iuvare, Vitam Gilleni propono metrificare.

The vita contains 240 lines and ends (f. 65 r):

Pro sancti merita data sit mihi caelica vita.

The poem on "miranda res sancti" starts immediately after on the same leaf.

Beg.: (D)e miranda re sancti volo versificare.

Quidam caecus erat quem iam Bracbantia gignit.

End: It strabo sospes cui iam fuit ex oculo spes. ${ }^{10}$

Overall, these two texts contain 335 lines imitating dactylic hexameters, but with little respect for the rules of prosody. The long syllables frequently count as short, e.g., f. $61 \mathrm{r}, 1.18$ : orăculum, and vice versa, e.g., strābo in $l l$. 24 and 27 of f. 66v. The hexameters are usually rhymed with additional homoioteleuta in the caesurae; see, e.g., the first two lines: "iuvare"/"metrificare" and "veni/Gilleni." Sometimes the hemistich rhymes with the clausula within the same line, e.g., f. 61r, l.13: "Gillenus mores// Petri recolensque dolores." Sometimes the hemistich rhymes with the 


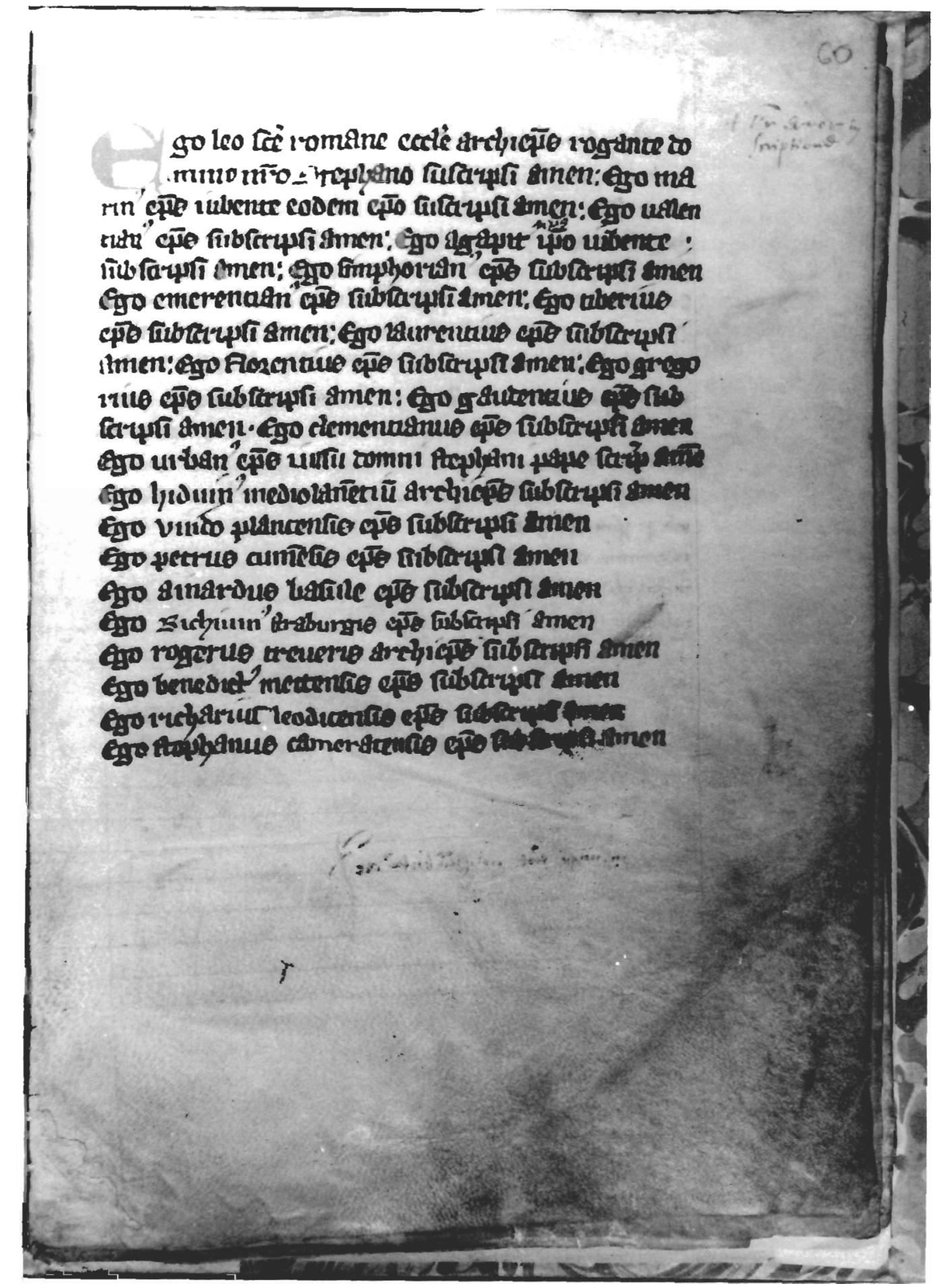

Fig. 16. Episcopal subscriptions to a papal decree concerning the monastery of St. Gerard at Brogne (f. 60r). (Courtesy of Department of Rare Books and Special 'Collections) 
clausula of the following line while the clausula of the first line rhymes with the hemistich of the following line, e.g., f. 61r, ll.3-4: "Gillenus nalus// fuit olim sanguine graeco/ atticus; at de quo// sum quid narrare paratus." This last example illustrates, as well, some peculiar rules of phonetics followed by the author: "graeco" and "de quo" are made to rhyme.

This Vila sancli Gisleni is one of the two known medieval versified lives of this saint; the other one by an anonymous XIIth century author was published by $G$. Harster. ${ }^{11}$ In all, there are ten known medieval "vitae sancti Gisleni" and these have been listed in Potthast's Bibliotheca Historica Medii $A e v i^{12}$ and published and commented upon by A. Poncelet in the Analecta Bollandiana. ${ }^{13}$ Our vita is listed as "vita nona" in both Potthast and Poncelet. The latter's edition and description of the manuscripts ${ }^{14}$ is based on the material provided by Baudry and Guesquière. ${ }^{15}$ As Poncelet suggests, there existed two manuscripts that contained "vita nona." One of them is Codex Parisiensis 11765 (ff. 75 sqq.); the other one, not clearly identified by Poncelet, is called by him simply the "apographum" or "transcript." This apograph had been analysed by Baudry, who concluded that it was written by the author himself, whom he identified as Stephanus de Warelles, 32nd or 33rd abbot of St. Ghislain, 1317-1366. ${ }^{16}$ However, Baudry's identification of the author of the "vita nona," or at least his reasoning, cannot be accepted for various reasons, of which some were presented by Poncelet. ${ }^{17}$ One more counter-argument to Baudry's attribution of his manuscript to the author is provided by our manuscript. A comparison of our text with the text published from the apograph, which does not include any readings from Codex Parisiensis, indicates that our manuscript is earlier than the codex Baudry considered to be the archetype. From a study of the apparatus criticus to the version of the vita nona published by Poncelet, it is clear that the apograph contains several strange readings that could result only from the misinterpretation of the ligatures by an inexperienced scribe. In our manuscript we find the correct ligatures: e.g., f. $64 \mathrm{v}, l .11$ "9plurib3" is a correct reading, "cum pluribus" while in the apograph we find "compluribus" which makes no sense in the context. Such an error reveals its origin, a wrongly resolved ligature, "cum" or "com-". Hence, the apograph is clearly copied from another manuscript with this ligature and thus is not an original copy. There are other similar examples: on the same folio $(64 \mathrm{v}), l$. 13 ,9pule," "cum praesule," in our manuscript against "compresule" of the apograph, "Ee," "curae," against "certe," etc. Moreover, the correct reading in our manuscript of an unusual word "mainriu" (f. $64 \mathrm{v}, l .23$ ) against "mamris" of the apograph, corrected to "mamriu"(?), leaves no doubt that our manuscript preceded the apograph. Thus, if either of the two should be held to be the author's copy, it would be our manuscript, not Baudry's. One more peculiarity of our text, this time of a hagiographical nature, should be mentioned. According to tradition, the saint's feast is on 9 October, supposedly the day of his death. However, our text follows a different tradition, one that appears to be unrecorded, indicating that he died in August: "Augusti mense coeli dedit ad regimen se."18

4. f. $67 \mathrm{r}$ is blank and the volume ends on $\mathrm{ff} .67 \mathrm{v}$ and 68 with a small collection of short versified moralistic and didactic cliches, written by the same hand as the recipe and the "vita" except probably for the last epigram on the triad of heros of pagan, biblical and Christian history. 
Beg.: T(itulus?): Primum (...?) regnum dei et omnia tibi
adicientur.

Ends: Inter Gentiles, Judaeos et Christicolentes.

Each poem is preceded in the margin by "Nou" (nostrum ?, sc. poëma), and it seems that the authorship of these poems should be attributed to the scribe, though at times they are merely his variations on some medieval loci communes. Thus, e.g., the first line of the poem "De divitis insufficientia" (f. $67 \mathrm{v}$ ) can be found in Walther's collection of medieval Latin proverbs: ${ }^{19}$ "Non est in mundo dives qui dicat: 'abundo'," in our manuscript: "...qui dicat habundo." However, the following lines in our manuscript are not listed among the variants recorded by Walther; our manuscript continues: "cum plus ditatur tanto (minus assatia-)tur." The "minus assatia-" was filled in later by the same hand that wrote the superscription preceding the vita (f. 61r) while a third hand, the same that added a marginal remark to the subscriptions (f. 60r), added another variant clause substituting "hoc saturatur" for "assatiatur." The convential nature of these epigrams makes them irrelevant to our discussion. They clearly have nothing in common with the cult of St. Gislenus, and were surely added to fill out the remaining blank leaves of the volume without respect to its monothematic content.

We can now return to the "subscriptiones episcoporum" in order to demonstrate that the original codex really was a monothematic anthology. These subscriptions contain twenty-two names using the formula: "Ego (...) episcopus (v. archiepiscopus) (iussu papae Stephani (...vel sim.)) subscripsi. Amen." It is clear at first sight that we are dealing with a list of witnesses to some papal decree. However, the composition of this list is a bit enigmatic. Its two most striking features are: (1) only the last nine names of the "non-Roman" bishops have the name of the see included, and (2) the text of the subscriptions containing the first thirteen names of the "Roman" bishops is continuous, while the last nine each use one line beginning with "ego."

A simple comparison of the names of the bishops whose sees are given with the indices of bishops and the tabulation of their terms of office ${ }^{20}$ lead us to date our list to the year 929 and to identify the pope mentioned as Stephen VII, whose brief reign lasted from 929 to 931. Furthermore, comparison of our list with the relevant clauses of papal decrees of this period enables us to identify it as a list of the episcopal witnesses to the privileges granted by Pope Stephen to the monastery at Brogne, Belgium, and presented personally to its founder St. Gerard. ${ }^{21}$ The phrasing used for our subscriptions is so similar to that of the corresponding clause of the full document that this identification seems to be absolutely certain.

However, there are two minor differences between our list and the papal bull and these arouse some suspicion as to the origin of our document. First of all, our list has one more name than the full document, the second on the list, Bishop Marinus. ${ }^{22}$ Actually, his name fits perfectly into this list, since it is the name of the pope whose reign began in 942 , so he may have been a bishop at the time this decree was issued, like two other bishops on our list who were elected pope later: Leo (Leo VII, 936-939), "Romanae ecclesiae archiepiscopus" and Agapitus (Agapitus II, 946-955), "episcopus." 
Secondly, in the full version of this document, the subscriptions of the last nine bishops have a different formulation from that of the first twelve; instead of "ego (....) subscripsi," they are phrased in the third person singular "(...) subscripsit." Besides, according to Bormans ${ }^{23}$ who analysed the full decree, the names of the last nine bishops in the bull he examined were written by a hand different from that of the first half of the list and all traced by the same pen. However, as we mentioned already, in our manuscript some of these names were filled in later. In order to throw some light on this detail, we should explain the origin of the document. From the Vita sancti Gerardi we learn that St. Gerard went to Rome to request papal approval for special privileges for his monastery. These were granted and the suggestion was made that he should ask the bishops of the cities through which he would pass on his return to Brogne to append their signatures to the privilege. This would explain the composition of the list of bishops who signed the document. We can infer that the first thirteen (twelve) bishops signed in Rome in the presence of the pope, while the other nine signed it successively as they were approached by Gerard. On the basis of the second part of the list, we can reconstruct the itinerary of Gerard's return to Brogne. Hence, we can conclude that while the papal bull was signed in the first person by the bishops present at Rome, "subscripsi," the names of the other bishops were simply recorded by the scribe in the third person, "subscripsit." But, how can we explain the fact that in our list all the names are recorded in the first person and why were several names filled in later?

It seems that the only possible explanation is to assume that the privilege to the monastery at Brogne is a forgery. This idea was first proposed by Bormans ${ }^{24}$ and more recently followed by Smet. ${ }^{25}$ Our manuscript adds more substance to their arguments. Although Bormans and Smet reject this bull as a complete forgery, we are inclined to suspect that there really existed some papal privilege for the monastery of Brogne which for some reason disappeared or was substantially damaged very early, perhaps only a few decades after it was issued. However, as the Vita sancti Gerardi, composed in the XIth century, ${ }^{26}$ stressed Gerard's visit to Rome and the papal privilege, the bull was reconstructed in order to provide documentation of the visit and of the privilege. It seems that the forger did not succeed in his reconstruction of the bull at the first try. This may explain the existence of two versions of the bull, the one already mentioned and the other much shorter one long known to be a forgery. ${ }^{27}$ This may also apply to the list of subscriptions. One version would have the names of "Roman" and "non-Roman" bishops differentiated by distinct formulas, while the other, like ours, would not. The use of the third person in the second half of the list may have been intended to add authority to the "vita," while the use of the first person there may have been intended to add authority to the bull itself. The forger's struggle with the reconstruction of the subscriptions could also be the reason behind the inclusion of Marinus in our manuscript. At some point, the forger discovered that he could be included with historical probability and thus Marinus became an extra witness.

It can not be excluded that in our manuscript we have a copy of a working draft of this alleged forger. This would be the most logical explanation of the fact that, as we have mentioned, three names of the bishops were written in later. Of these, two had their titles and sees written in with blanks left for their names. All three were "non-Roman" 
bishops. It would be too much of a coincidence that the scribe was unable to decipher three names in this very part of the codex or bull from which he copied. We must assume then that the forger first drew up the list of cities on Gerard's itinerary and only then tried to find the name of the bishop of each see. If he had a name available, he would write it down immediately; if he did not have a name, he left a blank and filled it in later when he discovered the name. Nevertheless, he made some errors: Richininus instead of Richwinus and the inclusion of $\mathrm{Hi}(1)$ duinus whose episcopate did not overlap with those of the other bishops. ${ }^{28}$ However, the assumption that our manuscript was a working draft of the alleged forger would, "eo ipso," alter the dating based on its palaeographical features. Thus, instead of dating our manuscript to the XIIIth century, we would have to attribute it to the XIth century if it were really linked with the "vita Gerardi" of that century. Since this dating is impossible on palaeographical grounds, we are forced to conclude that either there was a second, independent, forgery of the papal bull in the XIIIth century, or that the text used by our copist was so damaged that it was not possible to transcribe it directly.

Thus far we have discussed this document in isolation. Now we should place it in the context of the whole volume and ask what justified its inclusion in the anthology of literature dealing with St. Gislenus. For its inclusion we have two clues, one internal and one external. The internal clue is provided by the text of our versified "vita." Twice in this text there is mentioned "quidam Eggdus" which should be read as Eggradus. It is possible that here we have a trace of the name Gerardus in a quite distorted form. Our "vita" would then record one of the versions of the legend of St. Gislenus where the ghost of this saint appeared directly to Gerard, and not as in a more popular version to Gislebertus, Duke of Lorraine, in order to ask him to take over his faltering monastery in person. The external clue is provided by the Vita sancti Gerardi, in which we learn that Gerard was given the task of reorganizing the Gislenian monastery in Celle by Gislebertus, Duke of Lorraine. In this version of the story, St. Gislenus appeared to the duke in a dream and complained that the monks did not allow him to rest, but carried his body around the countryside in order to collect alms which they used for dishonest purposes. Gerard turned these monks out and replaced them by Benedictines. It is here that we meet historical fact. Gislebertus probably acted under the guidance of Stephen, Bishop of Cambrai, whose name, by the way, appears as the last one in the list of subscriptions, "Stephanus, Cameracensis episcopus." When this all probably happened, we do not know, since this incident in Gerard's life, like his visit to Rome, is obscured by legend. It likely occurred between 931 and 941 , but we still do not know for how many years Gerard acted as abbot of the monastery of St. Gislenus.

All the above results of our analysis of this manuscript seem to be sufficient for the reconstruction of its history and at the same time for the correction of some errors committed by scholars who dealt with related topics.

We assume that originally the text which we have discussed belonged to an anthology of literature on St. Gislenus compiled for liturgical and other purposes and similar to the Codex Cellensis KKKK quoted already in reference to the "prosa" and hymns to St. Gislenus. This volume could 
include, apart from purely Gislenian literature, some texts dealing indirectly with this saint, as, e.g., the privilege, or forged privilege, granted to St. Gerard. At some point however, probably after the fire that destroyed the monastery in Celle together with its library in $1728,{ }^{29}$ this codex became disbound and only a part survived, i.e., the folios which we have preserved together with some other texts on St. Gislenus. Later, these were bound together with fragments from other manuscripts that survived the fire to create a new compilation which was then foliated in Roman numerals. This new codex in our opinion should be identified as the lost Codex Cellensis MMMM. The description of this codex is to be found in the catalogue compiled by Baudry and included in his annals of the monastery of St. Gislenus. ${ }^{30}$ However, the data provided by Baudry himself, by the continuator of his annals, Durot, and by the publisher of the annals, Poncelet, are so vague and at times contradictory, that we learn nothing about the physical characteristics of this codex and nothing about its fate. We do not even know if, after Baudry, either his continuator or commentator had ever seen this codex; moreover, Baudry is not always reliable and one example of this is especially pertinent here. As the last among eighteen different texts making up this codex Baudry lists a mysterious "Vita sancti Kiri" of which he quotes the incipit: "Supplex oro veni me, Kiri, iuvare." This is obviously an error of transcription and is the initial verse of our "Vita sancti Gisleni" with "sancti" omitted between "Kyri" and "iuvare."

In Baudry's description of the whole codex, just before this "vita," we find the "privilegium Stephani papae concessum monasterio Broniensi, datum quinto calendas maii 913" of which in our manuscript only the subscriptions survive. The dating of this document has been discussed above. Furthermore, in the middle of this codex, item 9, we find "Prosa et hymni de Sancto Gisleno." Thus, we have in this codex all the texts that we found in our volume with exception of the recipe between the subscriptions and "vita" and the epigrams at the end. Owing to their irrelevance, these could easily have been omitted by Baudry. Also contained in this codex, according to Baudry's catalogue, were a commentary of the Cantica Canticorum by Rupert of Deutz (Robertus Tuitiensis), Sancti Gisleni vita septima, and several other hagiographical texts, including Legenda undecim millium virginum scripla a Stephano abbate $S$. Ghisleni which Baudry erroneously attributed to Stephanus de Warelles, the same XIVth century abbot of the monastery to whom he ascribed our "vita," the "vita nona." Faider, ${ }^{31}$ who discovered a manuscript, "Reliures 8683," in the library of Mariemont announced triumphantly that this manuscript was beyond doubt the only surviving remnant of Codex MMMM. However, in our opinion it is not the only surviving fragment of Codex MMMM and, indeed, not from this codex at all. First of all, the dimensions of the leaves of Faider's manuscript (188 x 123/150 × $95 \mathrm{~mm})$, much smaller than those of our manuscript $(230 \times 160 / 165 \times 105 \mathrm{~mm})$, prove that they both could not belong to MMMM. Faider's manuscript has no foliation signs; ours does and they fit perfectly with Baudry's description of MMMM. ${ }^{32}$ Finally, our manuscript contains four texts identical with the corresponding parts of MMMM, while Faider's identification of his manuscript with this codex is based arbitrarily on the identity of the title of only one work. All these factors favour the assumption that it is our manuscript that preserves portions of Codex Cellensis MMMM and not Faider's. "Eo ipso," we have to reject as well Poncelet's suggestion that his copy of the "vita nona" belonged to $\mathrm{MMMM}$. 
The history of the Codex Cellensis MMMM does not end here, but the information that we can discover about it is extremely confusing. Poncellet remarks in passing that $A$. Wins, who took possession of some of the manuscripts of the monastery of St. Gislenus, wrote in the margin of Baudry's catalogue next to the entry for MMMM the remark "retenu," 33 indicating that Wins kept this manuscript in his collection. However, this must be erroneous on the part of Poncelet, since no further details usually accompanying identifiable manuscripts are provided. In addition, there is no mention in the catalogue of Win's library of anything resembling this codex. $^{34}$ We must assume then that this codex, MMMM, shared the fate of many other codices from the monastery which, following the French Revolution, were sold for very low prices after the more interesting leaves had been removed. ${ }^{35}$ Someone probably considered the folios containing the "prosa" and the hymns especially interesting; it is significant that the only other surviving copy of these texts is also a single leaf. The same reason would explain the survival of the vita and the other texts. We suspect that the codex itself disappeared after it was sold, while the leaves that had been removed were still preserved together with other fragments of manuscripts. At some point, probably in the late XIXth century, our ten leaves were bound together with one of these manuscript fragments, namely, the truncated Aurora of Peter Riga. We know that the library at Celle had a volume containing the Aurora that had also disappeared. This volume, PPPP, ${ }^{36}$ also contained three other texts: Tractatus Hugonis de Sancto Victore super Lamentationes Jeremiae, Sermo $S$. Bernardi contra vitium ingratitudinis, and De morte quadruplici, all of which are lost. We have no details concerning the physical description of this volume, so we can not identify our Aurora with the corresponding part of manuscript PPPP without some reservations. However, such an identification is highly probable.

It is in the form and with the contents described above that our volume was acquired by the English collector George Dunn in $1904,{ }^{37}$ and then by McGill University in 1923. Here the volume ends its tumultuous history: a history that reflects that of the monastery founded by St. Gislenus in the VIIth century and of its once celebrated library. ${ }^{38}$

\section{Notes}

1. Seymour de Ricci (with the assistance of J. Wilson), Census of Medieval and Renaissance Manuscripts in the United States and Canada, (New York, 1937) II: 2214, item 118. The authors gratefully acknowledge the help of Dr. Faith Wallis, Osler Library, with the dating of these fragments on the basis of their palaeography.

2. For the general bibliography on this saint see: E. Reusens, Biographie Nationale, VII (1880-1883) 730-732; E. de Moreau, Lexicon für Theologie und Kirche, IV (1932) col. 508. For a more recent summary of the literature on St. Gislenus and on the library of his monastery in Celle, see: A. d'Haenens, "Gérard de Brogne à l'abbaye de Saint-Gislain (931-41?)," Révue Bénédictine, LXX (1960) 105-6, n.6. The only substantial later contribution to Gislenian studies is D. van Overstraeten, "Notes sur les dévotions populaires à StGhislain au Moyen Age," Valenciennes et les Pays-Bas. Mélanges offerts à 
Paul Lefrancq, IX (Valenciennes, 1976) 217-229.

3. The rudimentary elements of colometry are represented by the capital letters shaded in red at the beginning of each strophe in both the "prosa" and the hymns.

4. Published in Analecta Hymnica Medii Aevi, XII, pp. 124-5, nos. $218-$ 220. For the description of the manuscript of Celle (later Mons), see: P. Baudry et A. Durot, "Annales de l'abbaye de St-Ghislain," ed. A. Poncelet, Annales du cercle archéologique de Mons, XXVI (Mons, 1897), p. 399. As Baudry suggests (ibid.) these hymns were written just after 850 and were copied in this manuscript in the XIth century.

5. Published in Analecta Hymnica. XIII: 154-6, no. 58.

6. Referred to, Analecta Hymnica. XXVIII: 297, no. 100, but not published.

7. A. Poncelet in Analecta Bollandiana, VI (1887) 300-302; reprinted in Analecta Hymnica. LV: 172-3, no. 151 (prosa) and Analecta Hymnica. XXIII: 183-5, nos. 310-312 (hymns).

8. Analecta bollandiana 300 .

9. See: G. D. Gordini, "Gisileno," Bibliotheca Sanctorum (Rome, 1965) VI, col. 1149.

10. As a matter of fact, the very last line of this text is only a verse omitted in the middle of f. 66v: Pergens Melbodium fac si potes ut domicellae.

11. From the Codex Hagensis Z 68(684); G. Harster ed., Novem vitae sanctorum metricae ( Leipzig, Bibliotheca Teubneriana, 1887) 148-178.

12. A. Potthast, Bibliotheca Historica Medii Aevi. Wegweiser durch die Geschrichtswerke des Europäischen Mittelalters bis 1500 (Berlin, 1896², repr. Graz, 1957) II: 1342. Our vita figures also as no. 3561 (other vitae: nos. 3552-3560) in Bibliotheca Hagiographica Latina, ed. Socii Bollandiani, (Bruxelles, 1898-9, repr. 1949) I. In both cases only ed. princeps (see below) is indicated without any mention of manuscript sources.

13. Potthast. V (1886): 209-294; VI (1887): 209-302; XII (1893): 414-422.

14. In Potthast. VI: 291-300; also discussed on 212, 247-9 and 290-1.

15. In Analecta Bollandiana. VI: 211.

16. In "Annales de l'abbaye de St-Ghislain" (ed. de Reiffenberg) in Monuments pour servir à l'histoire des provinces de Namur, de Hainaut et de Luxembourg, VIII (1848): 209 in margin and 495.

17. Baudry stated that this vita was written by the same hand as another manuscript containing the Legenda 11000 virginum traditionally ascribed to Stephanus, though actually written about 200 years before his time; cf. 
Analecta Bollandiana. VI: 248-9.

18. In our manuscript f. $64 \mathrm{v}, 1.19$ and in Poncelet's edition, 1.214.

19. Carmina medii aevi posterioris latina $11 / 1-5$ : Proverbia sententiaeque latinitatis medii aevi (Gottingen, 1963-67), no. 17645.

20. E.g. P. B. Gams, Series episcoporum ecclesiae catholicae (Leipzig, $1931^{2}$ ).

21. The earliest editors of this document varied significantly in the dating of the bull and thus different popes named Stephen were believed to have issued it. In the manuscript from which it was published by Miraeus, Origines Benedictinae (Cologne, 1614) 42, the date is 27.IV.913 which is obviously wrong since there was no Pope Stephen at that time. He attributes this bull to 942; in this dating, also impossible, he follows Baronius, Annales Ecclesiastici, IX (Mayence, 1601) col. 824. This dating was first rejected by P. Pagi, Critica in Annales Baronii (Anvers, 1705) IV: 839. The Bollandists fixed the date at 929, Acta Sanctorum, L (1768) 245. As a matter of fact, the only problem with dating this bull seems to be caused by the mention of the archbishop of Milan, Hi(1)duinus, whose episcopate began in 932, so he could not have signed this document as archbishop in 929 . The bull was also published separately by E. de Marmol, "l'abbaye de Brogne où de Saint Gérard," Annales de la Société archéologique de Namur, V (1858) 420-422.

22. In Migne, Patrologia Latina, CXXXII, col. $1053 \mathrm{ff}$. In this edition of the document, one more name, Ainardus, is also omitted, but probably this is due only to an oversight of the editor.

23. S. Bormans, "Une fausse bulle de pape Etienne VIII," Bulletin de l'Académie Royale des Sciences, des Lettres et des Beaux-Arts de Belgique, ser. 2, XLVII (1879) 281 and n.2.

24. Bormans 271-296.

25. J. M. de Smet, "Recherches critiques sur la Vita Gerardi abbatis Broniensis," Révue Bénédiictine, LXX (1960) 5-61, and especially 12-17.

26. Cf.: L. von Heinemann, "Vita Gerardi, abbatis Broniensis," Monumenta Germaniae Historica, Scriptores, XV 654-5.

27. Cf. Acta sanctorum (ed.nova cur. J. Carnandet), L (octobris t, II), Paris, 1866 246-249.

28. Cf. Gams, for Richininus (Richwinus) see p. 315 and for $\mathrm{Hi}(1)$ duinus see 796.

29. Cf. Baudry 357.

30. Baudry 399-401.

31. See P. Faider, "Note sur un manuscrit provenant de l'abbaye de StGhislain," Révue Bénédictine, XLVIII (1936) 80-83. 
32. E.g., the prosa and the hymns to St. Gislenus are on folio 96 out of 205 folios, and in Baudry's description these texts are numbered 9 out of 18 , i.e. in both cased in the very middle of the whole corpus.

33. See: Baudry 399, n.1.

34. Cf. Analecta Bollandiana XII: 409 sqq.

35. Cf. Baudry 360-361: n.1.

36. Cf. Baudry 401. Under sign ZZ (ibid., p. 382) there is a Biblia metrificata, but this is dated 1462, so it is definitely not our Aurora which was written much earlier.

37. It is possible, as Dunn's agent suggested in a postcard inserted in our volume, that at some point it was in the possession of the library at Mons.

38. For the history of the library of St. Gislenus' monastery see: Catalogue des manuscrits de la Bibliothèque de Mons (Gand, 1931) xxivxxvii. 